\title{
The Application of Molecular Methods in Diagnostics of Phytopathogenic Viruses, Fungi and Fungus-Like Organisms
}

\author{
Ivana Stanković and Ana Vučurović
}

\begin{abstract}
The aim of this chapter is to describe some of the protocols which are used in the diagnostics of plant viruses, fungi and fungus-like organisms. Special adaptation of certain protocols is required for each of this group of pathogens and even more, for every type of virus, fungus or fungus-like organism, each type of raw material in terms of plant organs, plant host species, time of year and conditions in the laboratory. The protocols of molecular methods for detection, identification and characterization of phytopathogenic organisms cited here in include detailed instructions for its application. This chapter contains specific recommendations for selection of plant material, extraction of total RNAs or DNAs, detailed procedure for RT-PCR or PCR depending on phytopathogenic organisms and instruction for interpretation of obtained results. The chapter also focuses on application of DNA cloning in plant virology. The text on DNA cloning contains instruction for basic steps including amplification of DNA fragment that we want to clone, ligation of PCR product with vector DNA, insertation of recombinant DNA into bacteria cells, the reproduction
\end{abstract}

\section{How to cite this book chapter:}

Stanković, I. and Vučurović, A. 2019. The Application of Molecular Methods in Diagnostics of Phytopathogenic Viruses, Fungi and Fungus-Like Organisms. In: Vucelić Radović, B., Lazić, D. and Nikšić, M. (eds.) Application of Molecular Methods and Raman Microscopy/Spectroscopy in Agricultural Sciences and Food Technology, Pp. 59-82. London: Ubiquity Press. DOI: https://doi.org/10.5334/bbj.e. License: CC-BY 4.0 
of bacteria together with the recombinant DNA, screening clones with recombinant DNA, and plasmid extraction and purification from the bacterial cells.

\section{Molecular methods in plant virology and mycology}

Identification of plant pathogens, in addition to conventional methods, requires the use of a variety of different molecular methods, which contribute to the accuracy, reliability, speed and efficiency in phytopathology at all. In addition, the risk of introduction of invasive plant pathogens whether cultivated, ornamental plants or in natural communities (forests, pastures) grows as a result of globalization, increased mobility of people, climate changes and pathogens and vector evolution (Anderon et al. 2004; Miller et al. 2009).

Generally speaking plant pathogens, whether they are expansive (emerging), re-emerging (e.g., new races, pathotypes, forms resistant to pesticides or antibiotics), and chronic/endemic pathogens that are known and present for long time, but still can prompt epidemics, can cause economically significant yield losses (Strange \& Scott 2005). Because of this, the application of molecular methods is of great importance and it is impossible to get totally reliable results in the detection, identification and characterization of plant viruses, fungi and fungus like-organisms without the application of this group of methods (Miller et al. 2009).

Adequate and timely diagnosis of diseases and detection of pathogens are crucial for prompt protection of cultivated crops, as well as natural biocoenosis (forest ecosystems and pastures), or in order to undertake preventive or application of a small number of therapeutic measures. Errors during detection of pathogens and disease diagnosis may lead to applications of inadequate control measures, and thus to the reduction in yield or market value of the crop. Inadequate phytosanitary measures based on an irregular and out of time identification of causal agent of disease may lead to the introduction of new, invasive and quarantine pathogen if the pathogen is detected late, which can cause economically very negative impact on production in the country, as well as on the export of plant production products (Miller et al. 2009).

Conventional methods which are used in the detection of plant pathogens, are sometimes time consuming, tedious, and often require extensive experience and expertise of the person who is applies them. In the certain cases of closely related pathogens, conventional methods can lead to the wrong conclusion or to inaccurate levels of identification. Because of these limitations, several methods have been developed based on the properties of nucleic acids that make up the genome of plant pathogens. These methods are usually collectively referred to as molecular methods. There is a large number of molecular methods, and common to all of them is that they are fast (often significantly faster than conventional), reliable and specific. Usage of molecular methods allows the detection of pathogens in different parts of the host plants, as well as 
in different natural environments, such as water for drinking or irrigation or in soil (McPherson \& Møller 2000; Reece 2004).

Molecular methods are used in the science for various purposes since the late 50 's and early 60 's of the $20^{\text {th }}$ century, however the greates progress and the fastest development was achieved by Kary Mullis in 1983 with the invention of the Polymerase Chain Reaction (PCR). This breakthrough changed molecular biology completlly, as well as virtually all biological and other sciences that rely on it, and deal with the research of genes and genomes. Since the invention of PCR, a number of modifications are made to particular usages, so today this method has a very wide range of use in all spheres of life, from medicine, through criminology, to the production of food and control of food safety (McPherson \& Møller 2000).

PCR method has several basic components that are used in everyday laboratory work to create a large number of copies of a specific portion of DNA in laboratory tube. PCR actually functions as a DNA copier. Although seemingly simple, PCR is actually a complicated process which involves a large number of components/reactants. Some of them, such as the DNA matrix, at the beginning are present in a very low concentrations, but as the reaction is going on their concentration increases dramatically, while the concentration of some components (dNTP, primers) do not significantly changes during the process. Also, rapid changes in the temperature and the $\mathrm{pH}$ value have significant influence on the interaction of the molecules during the process of PCR. All this makes PCR at the same time very complicated, but it opens a large number of various possibilities for manipulation and analysis of DNA (McPherson \& Møller 2000).

In the following text we have listed some of the protocols which are daily used in the research of plant viruses, fungi and fungus-like organisms, including detailed instructions, as well as the positive experience acquired during the research. Each of this group of pathogens, and even more every type of virus, fungus or fungus-like organism, each type of raw material in terms of plant organs, plant host species, time of year and the conditions in the laboratory requires special adaptation of certain protocols. The following text contains specific recommendations gained on the basis of experience in working with molecular methods during the research at the Laboratory of Virology and Mycology, Department of Plant Pathology, Faculty of Agriculture, University of Belgrade.

\section{The application of molecular methods in detection of phytopathogenic viruses}

\subsection{Selection of plant material}

When selecting a starting plant material for preparation of samples for molecular analysis possible uneven distribution of viruses in the plant must be taken 
into account. In order to improve accuracy of test and obtaining valid results, it is recommended to prepare compound samples of the smaller pieces of leaves with more expressed symptoms from many different parts of plant. In the case of necrotic symptoms, green tissue that borders necrotic parts should be used. Young, fresh and fully developed leaves are recommended for usage, older parts of plants are to be avoided. With the aging or necrosis of plant tissue virus concentration decreases and successful detection is harder (Krstić et al. 2008, 2010).

\subsection{Extraction of Total RNA}

Before reverse transcription followed by polymerase chain reaction (RT-PCR) total ribonucleic acid (RNA) should be extracted from infected plant material. For this purpose numerous protocols for total RNA extraction from plant material are developed. Like commercial kits: RNeasy Plant Mini Kit (Qiagen, Hilden, Germany; https://www.qiagen.com) and RNAqueous Small Scale Phenol-Free Total RNA Isolation Kit (Ambion, Inc., Applied Biosystems, USA; http://www. appliedbiosystems.com/http://www.thermofisher.com) which includes usage of columns with membranes on which nucleic acid is attaching. However, if extraction of total RNA is from seeds or plant species with high concentration of polyphenols or starch, which easily can clog membranes (McKirdy et al. 1998), CTAB (hexadecyltrimethylammoniumbromide) is recommended method (Bekesiova et al. 1999; Zeng and Yang 2002; Iandolino et al. 2004). Application of these and other different commercial kits is somewhat more expensive, but it requires less training and experience and usually gives uniformed results, while the use of CTAB method ensures that the extraction is better adopted to the specific characteristics of the starting material (Krstić et al. 2008, 2010).

\subsubsection{Total RNA extraction using RNeasy Plant Mini Kit} (Anonymous, 2012b)

\section{Important Note:}

1. The RNeasy Plant Mini Kit comprises two buffers: Buffer RLT and Buffer RLC, containing guanidine thiocyanate and guanidine hydrochloride, respectively. Buffer RLT is commonly used. In the cases when guanidine thiocyanate causes solidification of the sample Buffer RLC should be used.

2. If the Buffer RLT precipitates during storage, redissolve it by heating.

3. All steps of the procedure must be done quickly and at room temperature.

4. Add $10 \mu \mathrm{l}$ of $\beta$-Mercaptoethanol per $1 \mathrm{ml}$ of the buffer, stored buffer solution at room temperature $\left(15-25^{\circ} \mathrm{C}\right)$. After addition of $\beta-$ Mercaptoethanol, the buffer should be used for up to 1 month. 
5. Before using Buffer RPE for the first time, add $4 \mathrm{ml}$ ethyl alcohol (96$100 \%)$ per each $\mathrm{ml}$ of buffer.

\section{Total RNA extraction protocol:}

1. Choose $100 \mathrm{mg}$ of the symptomatic plant material.

2. Homogenize chosen plant material in liquid nitrogen using, for example, a mortar and pestle. Transfer plant tissue together with liquid nitrogen into a $2 \mathrm{ml}$ microcentrifuge tube and add $450 \mu \mathrm{l}$ Buffer RLT or Buffer RLC, after liquid nitrogen was evaporated.

3. Vortex vigorously and incubate samples at $56^{\circ} \mathrm{C}$ for $1-3 \mathrm{~min}$.

4. After incubation, transfer the sample to a QIAshredder spin column (lilac) in collection tube and centrifuge at full speed for $2 \mathrm{~min}$. This centrifugation allows additional grind of plant material and retention of large parts of plant tissue.

5. Transfer only the supernatant in a new $2 \mathrm{ml}$ microcentrifuge tube without disturbing pellet forms during centrifugation and add $225 \mu \mathrm{l}$ of ethanol (96-100\%). Mix by pipetting.

6. About $650 \mu \mathrm{l}$ of the sample transfer to an RNeasy spin column (pink) in a $2 \mathrm{ml}$ collection tube and centrifuge at $\geq 10,000 \mathrm{rpm}$ for $15 \mathrm{~s}$.

7. Discard the liquid from collection tube and add $700 \mu \mathrm{l}$ Buffer RW1 to the RNeasy spin column.

8. Centrifuge sample at $\geq 10,000 \mathrm{rpm}$ for $15 \mathrm{~s}$ and discard the fluid from collection tube.

9. In order to wash membrane, add $500 \mu \mathrm{l}$ Buffer RPE to the RNeasy spin column and centrifuge at $\geq 10,000 \mathrm{rpm}$ for $15 \mathrm{~s}$. Discard the fluid from collection tube and reuse it in the next step.

10. Pipet new $500 \mu \mathrm{l}$ Buffer RPE to the RNeasy spin column and centrifuge at $\geq 10,000 \mathrm{rpm}$ for $2 \mathrm{~min}$.

11. To remove residues of ethanol or extraction buffer, transfer the RNeasy spin column in a new $2 \mathrm{ml}$ collection tube and centrifuge at full speed for $1 \mathrm{~min}$.

12. In order to elute RNA, transfer the RNeasy spin column in a new $1.5 \mathrm{ml}$ microcentrifuge tube and add 30-50 $\mu \mathrm{l}$ RNase-free water. Centrifuge at $\geq 10,000 \mathrm{rpm}$ for $1 \mathrm{~min}$.

13. Store isolated RNA at $-20^{\circ} \mathrm{C}$ or $-80^{\circ} \mathrm{C}$.

\subsubsection{Total RNA extraction using RNAqueous Small Scale Phenol- Free Total RNA Isolation Kit (Anonymous, 2008)}

\section{Important Note:}

1. Prior to the first use, add $100 \mathrm{ml}$ of $38.4 \%$ ethanol in water to obtain a $64 \%$ ethanol solution. 
2. Wash Solution \#2/3 Concentrate is supplied as a concentrate. Before using for the first time, add $64 \mathrm{ml} \mathrm{100 \%} \mathrm{ethaol} \mathrm{to} \mathrm{obtain} \mathrm{a} \mathrm{working} \mathrm{solution.}$

3. Briefly inspect the Filter Cartridges before use. If glass fiber filters are dislodged gently push the filter down to the bottom of the cartridge using RNase-free pipette tip.

4. Befor use heat Elution Solution in an RNase-free microcentrifuge tube in a heat block set to $70-80^{\circ} \mathrm{C}$.

5. Perform all centrifugation steps at $20-25^{\circ} \mathrm{C}$ in a standard microcentrifuge. Ensure that the centrifuge does not cool below $20^{\circ} \mathrm{C}$.

\section{Total RNA extraction according follow protocol:}

1. Weigh $60 \mathrm{mg}$ of plant material with syptoms.

2. Place the weighed tissue in liquid nitrogen, and grind thoroughly with a mortar and pestle. Allow the liquid nitrogen to evaporate, but do not allow the tissue to thaw. Add 12 volumes $(720 \mu \mathrm{l})$ Lysis/Binding Solution and $60 \mu \mathrm{l}$ Plant RNA Isolation Aid in completely homogenized material.

3. Transfer sample in to $2 \mathrm{ml}$ microcentrifuge tube and centrifuge for $2-3$ min at $10000-14000 \mathrm{rpm}$.

4. Carefully transfer the supernatant in to new $2 \mathrm{ml}$ microcentrifuge tube without disturbing the cell-debris pellet in the collection tube, and then add $720 \mu \mathrm{l} 64 \%$ ethanol. Mix the sample using pipette.

5. Apply the ethanol mixture to a Filter Cartridge assembled in a Collection Tube (the maximum volume that can be applied at one time is approximately $700 \mu \mathrm{L}$ ). Close the lid gently, and centrifuge for $1 \mathrm{~min}$ at 1000-14000 rpm (13000 rpm). Discard the flow-through and reuse the Collection Tube.

6. Repeat this step until the entire sample has been drawn through the filter. Note: Maximum $2 \mathrm{~mL}$ of sample mixture can be passed through the filter without clogging or exceeding its RNA binding capacity.

7. Apply $700 \mu \mathrm{L}$ Wash Solution \# 1 to the Filter Cartridge. Close the lid gently, and centrifuge for $1 \mathrm{~min}$ at $1000-14000 \mathrm{rpm}$ (13000 rpm). Discard the flow-through and reuse the Collection Tube.

8. Apply $500 \mu \mathrm{L}$ Wash Solution \#2/3 to the Filter Cartridge. Close the lid gently, and centrifuge for $1 \mathrm{~min}$ at $1000-14000 \mathrm{rpm}$ (13000 rpm). Discard the flow-through and reuse the Collection Tube.

9. Repeat this step using new $500 \mu \mathrm{L}$ Wash Solution \#2/3.

10. Discard the flow-through, centrifuge Filter Cartridge for $1 \mathrm{~min}$ at 1000-14000 rpm (13000 rpm).

11. Pipet $40 \mu \mathrm{l}$ Elution Solution preheated to $70-80^{\circ} \mathrm{C}$ to the center of the Filter Cartridge and centrifuge for $30 \mathrm{~s}$ at $1000-14000 \mathrm{rpm}$ (13000 rpm).

12. Repeat this step using new $10 \mu \mathrm{l}$ Elution Solution.

13. Isolated RNA store at $-80^{\circ} \mathrm{C}$. 


\subsubsection{Total RNA extraction using CTAB method}

(Bekesiova et al. 1999)

\section{Important note:}

1. Using CTAB method homogenization is done with $2 \%$ CTAB, $2 \%$ PVP K 25, $100 \mathrm{mM}$ Tris-HCL, $25 \mathrm{mM} \mathrm{Na-EDTA}$ and $2 \mathrm{M} \mathrm{NaCl}$ extraction buffer $\mathrm{pH}$ 8.0. Prepared buffer is stored at room temperature under diffuse light.

2. Before using extraction buffer, itshould beadded $20 \mu$ lof $\beta$-Mercaptoethanol $(\beta-\mathrm{ME})$ per $1 \mathrm{ml}$ of the buffer. After addition of $\beta-\mathrm{ME}$, the buffer must be stored at room temperature $\left(15-25^{\circ} \mathrm{C}\right)$ and should be used for up to 1 month.

3. Before isolation prepare chlorophorm:isoamyl alcohol mixture in $24: 1$ proportion, $10 \mathrm{M} \mathrm{LiCl}$ and $3 \mathrm{M}$ sodium acetate $\mathrm{pH}$ 5.2.

4. Perform all centrifugation steps at $4^{\circ} \mathrm{C}$.

5. Transfer certain amount of extraction buffer into microcentrifuge tube and preheat it at $65^{\circ} \mathrm{C}$ in a water bath.

\section{Total RNA extraction protocol:}

1. Use up to $100 \mathrm{mg}$ of plant material.

2. Homogenize plant tissue in liquid nitrogen with a mortar and pestle. Transfer plant tissue together with liquid nitrogen into a $2 \mathrm{ml}$ microcentrifuge tube and add $700 \mu$ of preheated extraction buffer, after liquid nitrogen was evaporated.

3. Vortex vigorously. Incubation for $10 \mathrm{~min}$ at $56^{\circ} \mathrm{C}$ may help to disrupt the tissue, periodically shake microtube.

4. After incubation add $700 \mu \mathrm{l}$ of chloroform: isoamyl alcohol mixture in 24:1 proportion. Centrifuge at $4^{\circ} \mathrm{C}$ for $10 \mathrm{~min}$ at $10000 \mathrm{rpm}$.

5. After centrifuge three phases are phormed. Tranfer top phase, which contains RNA, into new $2 \mathrm{ml}$ microtube and add another $700 \mu \mathrm{l}$ of chloroform: isoamyl alcohol mixture in 24:1 proportion.

6. Centrifuge at $4^{\circ} \mathrm{C}$ for $10 \mathrm{~min}$ at $10000 \mathrm{rpm}$.

7. After cetrifuge transfer top phase into new $2 \mathrm{ml}$ microtube and add 175 $\mu \mathrm{l} 10 \mathrm{M} \mathrm{LiCl}$. Incubate over night at $4^{\circ} \mathrm{C}$.

8. Centrifuge at $4^{\circ} \mathrm{C}$ for $20 \mathrm{~min}$ at $10000 \mathrm{rpm}$ to form RNA pellet. Discard supernatant, pellet disolve by adding $50 \mu \mathrm{l}$ of DEPC water.

9. Precipitate RNA by adding $70 \mu \mathrm{l}$ of $3 \mathrm{M}$ sodium acetate ( $\mathrm{pH} 5.2$ ), $1750 \mu \mathrm{l}$ $96 \%$ ethanol and $30 \mathrm{~min}$ incubation at $-70^{\circ} \mathrm{C}$.

10. After incubation centrifuge at $4^{\circ} \mathrm{C}$ for $20 \mathrm{~min}$ at $10000 \mathrm{rpm}$. Discard supernatant, wash pellet by adding $1 \mathrm{ml}$ of $75 \%$ ethanol.

11. Centrifuge at $4^{\circ} \mathrm{C}$ for $5 \mathrm{~min}$ at $10000 \mathrm{rpm}$ to form RNA pellet. Discard supernatant, let pellet to dry at room temperature. 
12. After all ethanol evaporate disolve RNA in $30 \mu \mathrm{l}$ of RNase free water by mixing it with pipette.

13. Isolated RNA store at $-80^{\circ} \mathrm{C}$.

\subsection{RT-PCR method}

The vast majority of plant viruses are single-stranded RNA viruses with plussense polarity and for its detection, using PCR, are necessary to translate previously viral RNA into complementary DNA strand (cDNK). This step is referred to as reverse transcription or RT step.

RT step and PCR may be carried out as two separate processes in a single step or one after other in the same reaction tube. Application of "One-step" RTPCR protocol presumes combination of two enzymes and has several advantages compared to protocol that takes place in two stages. The main advantage is that the reverse transcription of isolated RNA to cDNA and the amplification of cDNA itself taking place in the same tube, thus reducing the risks of possible contamination of the test sample. The continuous RT-PCR, in which RT and PCR methods make continuous reaction, is more sensitive from protocol that takes place in two separate steps (Sellner \& Turbet 1998).

\section{Procedure for OneStep RT-PCR Kit (Anonymous, 2012a) Important notes before starting:}

- The QIAGEN OneStep RT-PCR Enzyme Mix contains HotStarTaq DNA Polymerase that must be activated befor amplification. Incubation at $95^{\circ} \mathrm{C}$ for 15 min activates this polymerase but also inactivates the reverse transcriptases.

- Using The QIAGEN OneStep RT-PCR Kit with gene-specific primers at a final concentration of $0.6 \mu \mathrm{M}$, amplification of nonspecific products is avoided.

- All reactions must be carried out on ice and preheat thermal cycler to $50^{\circ} \mathrm{C}$ before put samples in it.

- Final concentration of $\mathrm{MgCl}_{2}$ in the reaction mix is $2.5 \mathrm{mM}$, which provides adequate results.

- Preparation of reaction mix must be done in sterile, RNase-free area, separated from that used for RNA isolation or PCR product analysis.

- To avoid cross-contamination, tips with hydrophobic filters should be used.

\section{Instructions and preparation}

\section{Preparation and storage of QIAGEN OneStep RT-PCR kit}

1. The QIAGEN OneStep RT-PCR should be stored immediately upon receipt in laboratory at $-20^{\circ} \mathrm{C}$ in a constant-temperature freezer. 
2. The QIAGEN OneStep RT-PCR Enzyme Mix always stays in a freezer at $-20^{\circ} \mathrm{C}$. Do not centrifuge and vortex. As soon as you take the necessary amount for PCR-mix, return it into the freezer.

3. The 5x QIAGEN OneStep RT-PCR Buffer and dNTP Mix are divided into smaller portions that are stored in a freezer at $-20^{\circ} \mathrm{C} .5 \mathrm{x}$ QIAGEN OneStep RT-PCR Buffer divided into tubes per $50 \mu \mathrm{l}$, dNTP Mix per 10 $\mu \mathrm{l}$. Quantities that are used daily keep in a refrigerator at $4^{\circ} \mathrm{C}$.

4. RNase-free water when the first thaw out, kept in a refrigerator at $4^{\circ} \mathrm{C}$.

5. Each ingredient of Kit (except enzyme mix), before putting PCR-mix, is briefly vortex (vortex is especialy necessary for $\mathrm{MgCl}_{2}$ because it affect of its activity) and centrifuge (10 s at $5000 \mathrm{rpm} / \mathrm{min}$ ). When all ingredients of PCR-mix is poured into the tube, it is briefly vortex or mixed by pipetting while adding each reagent before PCR-mix is pour into the tubes for individual samples.

\section{Procedure for RT-PCR:}

1. To avoid localized differences in concentration, thaw isolated RNA, primers, dNTP Mix, and 5x QIAGEN OneStep RT-PCR Buffer, vortex vigorously and centrifuge at $5000 \mathrm{rpm}$ for 10 seconds. After that put all components on ice.

2. Prepare a reaction mixture using all the components required for RTPCR, except the template RNA, which in its composition and quantity corresponds to the recommendations from Table 1. A negative control

\begin{tabular}{|c|c|c|}
\hline Component & Volume/reaction & Final concentration \\
\hline \multicolumn{3}{|c|}{ Master mix } \\
\hline RNase-free water (provided) & Variable & - \\
\hline 5x QIAGEN OneStep RT-PCR Buffer & $10 \mu \mathrm{l}$ & $1 \mathrm{x}$ \\
\hline $\begin{array}{l}\text { dNTP Mix (containing } 10 \mathrm{mM} \text { of each } \\
\text { dNTP) }\end{array}$ & $2.0 \mu \mathrm{l}$ & $\begin{array}{l}400 \mu \mathrm{M} \text { of each } \\
\mathrm{dNTP}\end{array}$ \\
\hline Primer A & $3.0 \mu \mathrm{l}$ & $0.6 \mu \mathrm{M}^{1}$ \\
\hline Primer B & $3.0 \mu \mathrm{l}$ & $0.6 \mu \mathrm{M}^{1}$ \\
\hline $\begin{array}{l}\text { QIAGEN OneStep RT-PCR Enzyme } \\
\text { Mix }\end{array}$ & $2 \mu \mathrm{l}$ & - \\
\hline Template RNA (added at step 4) & Variable & $1 \mathrm{pg}-2 \mu \mathrm{g} /$ reaction \\
\hline Total volume & $50 \mu \mathrm{l}$ & - \\
\hline
\end{tabular}

Table 1: Reaction components for one-step RT-PCR mix in volume of $50 \mu \mathrm{l}$.

${ }^{1} \mathrm{~A}$ final concentration of $0.6 \mu \mathrm{M}$ of primers in the reaction mixture produces satisfactory results in most cases. However, sometimes using other primer concentrations $(0.5-1.0 \mu \mathrm{M})$ may give better results. 
(RNase free water) and a positive control (RNA of the reference isolate) should be included in each experiment.

Note: If it is not possible to measure the extracted RNA concentration using a spectrophotometer, it is suggested to add $2 \mu \mathrm{l}$ RA sample to $50 \mu \mathrm{l}$ of reaction volume.

1. Mix the master mix thoroughly, and dispense appropriate volumes ( $48 \mu \mathrm{l})$ into PCR tubes, for each sample.

2. Add template RNA ( $\leq 2 \mu \mathrm{g} /$ reaction) to the individual PCR tubes. Between samples must be altered extensions pipette and carefully handle the microtubes to avoid the formation of aerosols and possible contamination.

3. Put microtubes into the thermal cycler programmed according to the conditions shown in Table 2. The temperatures and cycling times, as well as number of cycling depend on virus-primers combination and the conditions are necessary to adjust for each specific primer pair.

\begin{tabular}{|l|l|l|l|}
\hline Conditions in Thermal cycler & Duration & $\mathrm{t}^{\circ} \mathrm{C}$ & Number of cycles \\
\hline Reverse transcription & $30 \mathrm{~min}$ & $50^{\circ} \mathrm{C}$ & \\
\hline Initial PCR activation & $15 \mathrm{~min}$ & $95^{\circ} \mathrm{C}$ & \\
\cline { 1 - 3 } Denaturation & $0.5-1 \mathrm{~min}$ & $94^{\circ} \mathrm{C}$ & \multirow{2}{*}{$25-40$} \\
\cline { 1 - 2 } Annealing & $0.5-1 \mathrm{~min}$ & $50-68^{\circ} \mathrm{C}$ & \\
\cline { 1 - 3 } Extension & $1 \mathrm{~min}$ & $72^{\circ} \mathrm{C}$ & \\
\cline { 1 - 3 } Final extension & $10 \mathrm{~min}$ & $72^{\circ} \mathrm{C}$ & \\
\hline
\end{tabular}

Table 2: Thermal cycler conditions for application of QIAGEN OneStep RTPCR Kit.

Note: Before amplification, hold the microtubes on the ice until Thermal cycler is warmed to $50^{\circ} \mathrm{C}$.

Note: After amplification, store samples at $2-8^{\circ} \mathrm{C}$ overnight, or at $-20^{\circ} \mathrm{C}$ for longer period.

\section{The application of molecular methods in detection of phytogenetic fungi and fungus-like organisms}

\subsection{Selection of plant material for DNA extraction}

Detection of phytogenetic fungi and pseudofungy by PCR method could be done after DNA extraction directly from plant tissue, leaf or branches, or from pure mycelium culture which are identified based on morphological characteristics. 
In both cases DNA could be efficiently extracted by using described method. If DNA extraction is done from pure mycelium culture they need to be grown in liquid culture and segregate mycelia from agar in nutrient medium.

\subsection{Growing mycelium for DNA extraction}

There are a few different liquid mediums for growing mycelium which are usually adopted to the specific characteristics of fungi or pseudofungy which is subject of research. The most commonly used are potato dextrose broth (PDB) and pea broth $(\mathrm{PB})$.

PDB (potato dextrose broth) is prepared of $200 \mathrm{~g}$ of potato and $20 \mathrm{~g}$ of dextrose in $1 \mathrm{l}$ distillated water, all together autoclaved $15 \mathrm{~min}$ at $121^{\circ} \mathrm{C}$. Diffuse $150 \mathrm{ml}$ of PDB in Erlenmeyer bulb and sterilize, then sow with five fragments of colony $\left(1 \mathrm{~cm}^{2}\right)$ from older cultures, reared on the PDB or other medium at $24^{\circ} \mathrm{C}$ in the dark. Seeded Erlenmeyer bulbs incubate for 15 days in the dark, at $24^{\circ} \mathrm{C}$ occasionally mixing with horizontal rotation. Liquid cultures of selected isolates are filtered over a layer of filter paper, then collect mycelium and dry under vacuum. Divide dried mycelia in parts of $100 \mathrm{mg}$, froze at $-80^{\circ} \mathrm{C}$, and keep in that condition until use (Konstantinova et al. 2002).

$\mathrm{PB}$ (pea broth) liquid medium is prepared of $120 \mathrm{~g}$ of frozen pea and $11 \mathrm{lof}$ distillated water, all together autoclaved $15 \mathrm{~min}$ at $121^{\circ} \mathrm{C}$. After sterilization filter medium and diffuse in prepared Erlenmeyer bulbs, $150 \mathrm{ml}$ per isolate. Again sterilize Erlenmeyer bulbs by $15 \mathrm{~min}$ autoclaving at $121^{\circ} \mathrm{C}$ and seed fragments of pure 7 days old cultures, tested by rearing on CPA at $20^{\circ} \mathrm{C}$ in dark. Incubation of seeded Erlenmeyer bulbs is carried out at room temperature in terms of natural shifts day and night during 7 days. After the expiry of incubation collect developed mycelium without fragments of agar and keep at $-80^{\circ} \mathrm{C}$ until extraction (Kroon et al. 2004).

\subsection{DNA extraction}

Method of polymerase chain reaction is preceded by extraction of total desoxyribonucleic acid (DNA). There are several protocols for extraction, as well as commercial kits. The most used are methods using DNeasy Plant Mini Kit (Qiagen, Hilden, Germany; https://www.qiagen.com) and standard CTAB (Cetyltrimethylamonium bromide) method (Day \& Shattock 1997).

\subsubsection{DNA extraction using DNeasy Plant Mini Kit (Anonymous, 2015a)}

All components of DNeasy Plant kit, including RNase A liquid keep in dry condition, at room temperature $\left(15-25^{\circ} \mathrm{C}\right)$, and under this condition they are stable for one year. 
Note: This procedure is provided to process maximum of $100 \mathrm{mg}$ of plant material. Using of larger quantities may adversely affect the success of extraction.

DNA isolation protocol with explanations:

\section{Important notes before starting:}

- Buffers AP1 and AP3/E concentrate may form precipitates and turn yellow upon storage. This does not affect its efficiency.

- All steps of centrifugation perform at room temperature $\left(15-20^{\circ} \mathrm{C}\right)$ in a microcentrifuge.

- To redissolve Buffer AP3/E, warm it up to $65^{\circ} \mathrm{C}$. Ethanol must be added after heating.

- To obtain working solutions of AW and AP3/E buffers, appropriate amount of ethanol (96-100\%) should be added.

- Buffer AE should be warmed to $65^{\circ} \mathrm{C}$.

1. Homogenize plant or fungal material using liquid nitrogen and mortar and pestle or tube and pestle. Transfer obtained homogenate to tube leaving liquid nitrogen to evaporate. Proceed immediately with procedure until the sample thawed.

2. Put $400 \mu \mathrm{l}$ of AP1 Buffer and $4 \mu \mathrm{l}$ of RNase A to $100 \mathrm{mg}$ of ground tissue and mix it vigorously until no tissue clumps are visible. If needed, pipette supernatant to remove clumps because clumps are difficult to lyse and therefore could lower DNA yield.

3. To lyse the cells, put tube to incubation for $20 \mathrm{~min}$ at $65^{\circ} \mathrm{C}$. During incubation, mix them 2-3 times manualy by flipping them up and down.

4. After incubation, add $130 \mu \mathrm{l}$ of AP2 buffer and incubate mixture for $5 \mathrm{~min}$ on ice. In this step polysaccharides and proteins are being precipitated together with remain of detergent from previous steps.

5. In the case when lysate is very viscous, centrifuge it for $5 \mathrm{~min}$ at maximum speed. Pipette supernatant to QIAshredder spin column (lilac).

6. Centrifuge QIAshredder spin column for $2 \mathrm{~min}$ at maximum speed. After centrifugation, most precipitates and cell debris stays on column. Pipette liquid from collection tube making sure not to disturb pellet which could be formed.

7. Use a new tube to transfer approximately $450 \mu \mathrm{l}$ of flow-through lysate from previous step.

8. Add Buffer AP3/E to lysate and mix it by pipetting, not vortex, immediately. For $450 \mu$ l lysate amoun of $675 \mu \mathrm{l}$ of Buffer AP3/E must be added.

9. Transfer $650 \mu \mathrm{l}$ of the mixture from previous step, toghether with precipitate could be formed, onto the new DNeasy mini spin column and centrifuge for $1 \mathrm{~min}$ at $\geq 6000 \mathrm{x}$ g. Discard flow-through and use same collection tube in next step.

10. Repeat previous step using remaining sample. 
11. Use a new $2 \mathrm{ml}$ collection tube to place DNeasy column. Apply $500 \mu \mathrm{l}$ of Buffer AW to the DNeasy column and centrifuge for $1 \mathrm{~min}$ at $\geq 6000 \mathrm{x} \mathrm{g}$ $(\geq 8000 \mathrm{rpm})$. After centrifugation discard the flow-through and reuse the same collection tube in the next step.

12. Apply another $500 \mu \mathrm{l}$ of Buffer AW to the DNeasy column and centrifuge for $2 \mathrm{~min}$ at maximum speed. After centrifugation discard collection tube together with flow-through.

13. Carefully transfer the DNeasy column to a $2 \mathrm{ml}$ microcentrifuge tube (making sure that column does not contact with ethanol in collection tube) and pipette $100 \mu \mathrm{l}$ of Buffer AE directly onto the DNeasy membrane (preheat Buffer $\mathrm{AE}$ to $65^{\circ} \mathrm{C}$, previously). Leave tube for $5 \mathrm{~min}$ at room temperature. After incubation, centrifuge tube for $1 \mathrm{~min}$ at $\geq 6000 \times \mathrm{g}$ $(\geq 8000 \mathrm{rpm})$ to elute DNA from membrane. If higher final concetration of DNA is needed, elute mambranes with $50 \mu \mathrm{l}$. If larger amounts of DNA are expected, elute mambranes with $200 \mu$ l.

14. If needed, previous step could be repeated in the same or in a new tube.

15. Isolated DNA is stored at $-20^{\circ} \mathrm{C}$ or $-80^{\circ} \mathrm{C}$.

\subsubsection{The extraction of DNA using a CTAB method (Day \& Shattock 1997)}

1. Homogenize $100 \mathrm{mg}$ of frozen mycelium at $-80^{\circ} \mathrm{C}$ in the presence of liquid nitrogen, and then add $800 \mu \mathrm{l}$ of extraction buffer.

2. The resulting suspension is transferred to a microtubule volume of $2 \mathrm{ml}$ and incubated in a water bath at $65^{\circ} \mathrm{C}$ for a period of $1 \mathrm{~h}$. Every $15 \mathrm{~min}$ utes the contents mixed thoroughly. During this part of the extraction leads to the degradation of the cell walls and release the cell contents.

3. In each microtubules add $600 \mu \mathrm{l}$ of chloroform and mix on the Vortex 10 seconds, and then centrifuged for $10 \mathrm{~min}$ at $13000 \mathrm{rpm}$.

4. After centrifugation consists of two different phases. The upper layer, the approximate volume of about $500 \mu \mathrm{l}$, pipetted to a new microtube tube, then add $300 \mu \mathrm{l}$ of isopropanol and incubated for $10 \mathrm{~min}$ at room temperature, and then centrifuged for $10 \mathrm{~min}$ at $13000 \mathrm{rpm}$.

5. The supernatant is carefully poured away, and the residue was rinsed with $600 \mu \mathrm{l}$ of $70 \%$ ethanol and centrifuged for $10 \mathrm{~min}$ at $13000 \mathrm{rpm}$.

6. Decant the liquid phase, and the microtube dry at room temperature for $3 \mathrm{~min}$ or at $56^{\circ} \mathrm{C}$ in a heating block.

7. The resulting pellet resuspended in $50 \mu \mathrm{l}$ TE buffer.

8. Isolation of DNA stored at $-80^{\circ} \mathrm{C}$.

\section{The composition of the buffer for the isolation}

$100 \mathrm{mM}$ Tris $\mathrm{HCl}, \mathrm{pH} 8.0$

$1.4 \mathrm{M} \mathrm{NaCl}$ 
20 mM EDTA

2\% CTAB (cetyltrimethylammonium bromide) $\mathrm{pH} 8.0$

\section{The composition of TE buffer}

$10 \mathrm{mM}$ Tris- $\mathrm{HCl} \mathrm{pH} 8.0$

1 mM EDTA

\subsection{Application of conventional PCR}

Reliable and sensitive method for the detection of pathogenic fungi from mycelium is implemented using universal primers ITS1/ITS4 (White et al. 1990). This pair of universal primers allows amplification and subsequent sequencing of the ITS region of ribosomal DNA of eukaryotes. ITS region is highly variable among morphologically different fungi species but it is conservative at the species level and in many genera of plant pathogenic fungi and it is used for phylogenetic analysis. ITS1/ITS4 is primers pair that can amplify the ITS region of eukaryotes and it can be used to check the success of DNA extraction. In addition, these primers are included in the survey in order to test their suitability for use within the protocol to sequencing identification. This method is proved to be reliable for the detection of various plant pathogenic fungi.

Prepare PCR master mix (reaction mixture) using 2x PCR master mix (ThermoFisher Scientific; http://www.thermofisher.com), which in its composition and quantity corresponds to the recommendations from the table.

\begin{tabular}{|l|l|l|}
\hline \multicolumn{1}{|c|}{ Components } & \multicolumn{1}{|c|}{ 1 sample } & No. of samples $+{ }^{1} \mathbf{K}^{+}+\mathbf{n B}+\mathbf{n R}$ \\
\hline RNase-free water & $9 \mu \mathrm{l}$ & \\
\hline $\begin{array}{l}\text { 2x PCR master mix (ThermoFisher } \\
\text { Scientific) }\end{array}$ & $12.5 \mu \mathrm{l}$ & \\
\hline Primer 1 concentration of $10 \mu \mathrm{M}$ & $1.25 \mu \mathrm{l}$ & \\
\hline Primer 2 concetration of $10 \mu \mathrm{M}$ & $1.25 \mu \mathrm{l}$ & \\
\hline Sample (template DNA) & $1 \mu \mathrm{l}$ & \\
\hline Total volume & $25 \mu \mathrm{l}$ & \\
\hline
\end{tabular}

Table 3: Quantities and components for prepareing the PCR mix in a volume of $25 \mu \mathrm{l}$.

${ }^{1} \mathrm{~K}+-$ positive control; $\mathrm{nB}$ - appropriate number of negative controls (Blank); $\mathrm{nR}$ - appropriate number of excess working reagent losses during manipulation; $\mathrm{n}=$ number of samples/10. (For every 10 samples to be tested, add one negative control (PCR mix with RNase free water) and capacity for another sample for the loss of reagents during manipulation. The amount of each component of PCR mix is multiplied by this number and added to the tube for the master mix) 
Master mix is prepared in a separate, preferably sterile, in a laminar flow hood. The required ingredients are prepared, so that the solution of PCR mix and primers are melted, thoroughly mixed on vortex and then centrifuged briefly (10 seconds at $5000 \mathrm{rpm} / \mathrm{min}$ ) in order to avoid localized differences in the concentration. In one microtube of $0.5 \mathrm{ml}$ or more if necessary, pour in the measured quantities for the required number of samples and the negative controls following the recommendations below the table. All the ingredients except the DNA sample are poured. Thus prepared master mix is stirred on vortex and centrifuged briefly (10 seconds at $5000 \mathrm{rpm} / \mathrm{min}$ ).

In prepared and marked $0.2 \mathrm{ml}$ microtubes dispense by $24 \mu \mathrm{lmix}$, and then adds the extracted sample DNA and mixed by pipetting. Between samples must be changed extensions for micropipette. Microtubes is then centrifuged in order to equalize the concentration and placed in the Thermal cycler programmed according to the conditions shown in the table.

\begin{tabular}{|l|l|l|l|}
\hline Conditions in Thermal cycler & \multicolumn{1}{|c|}{ Duration } & \multicolumn{1}{|c|}{$\mathbf{t}^{\circ} \mathbf{C}$} & \multirow{2}{*}{ Number of cycles } \\
\hline Initial denaturation & $2-5 \mathrm{~min}$ & $95^{\circ} \mathrm{C}$ & \\
\cline { 1 - 3 } Denaturation & $0.5-1 \mathrm{~min}$ & $94^{\circ} \mathrm{C}$ & \multirow{2}{*}{$25-40 \mathrm{x}$} \\
\cline { 1 - 2 } Annealing & $0.5-1 \mathrm{~min}$ & $50-68^{\circ} \mathrm{C}$ & \\
\cline { 1 - 3 } Extension & $1 \mathrm{~min}$ & $72^{\circ} \mathrm{C}$ & \\
\cline { 1 - 2 } Final extension & $10 \mathrm{~min}$ & $72^{\circ} \mathrm{C}$ & \\
\hline
\end{tabular}

Table 4: Thermal cycler conditions for PCR reactions.

As a positive reaction is considered to be the occurrence of the amplicon of about 500-600 bp, which must be present in the positive control (DNA extracted from reference isolates) and which should not be present in the B (blank - PCR mix with RNase free water) - negative control.

\section{Analysis of PCR products}

Whether applied in the study of plant pathogenic viruses or fungi and funguslike organisms, after completing the PCR reaction it is necessary to make the results visible in order to be analyzed. The resulting product of amplification can be detected in several ways, but the most often is using agarose gel electrophoresis. Depending on the size of the PCR product, prepared gel with various concentrations of agarose (1-2\%), stained with Ethidium bromide (EtBr) and examined under UV transilluminator (Lee et al. 2012).

If the size of the expected fragments is about $1000 \mathrm{bp}$, which is usually the case in the detection and characterization of viruses, and plant pathogenic fungi, a $1 \%$ agarose gel is used. The gel is loaded with all analyzed samples, all positive and negative controls as well as markers with fragments in the appropriate size range. 


\section{Preparation of the gel and gel electrophoresis (Lee et al. 2012)}

1. Prepare $1 \%$ agarose gel by the addition of an appropriate mass of agarose in $1 x$ TBE buffer.

2. Place and fix separators in the gel tray to create a mold. Also, put the combs into the gel mold to creat the wells.

3. Warm solution of agarose and buffer up to boil in a microwave (about 30 $\mathrm{s}$, or until the agarose is melted).

4. Cool the melted agarose to a temperature of $50-60^{\circ} \mathrm{C}$ under the tap water and pour it in the gel mold with combs. When pouring the gel be careful do not create air bubbles.

5. Place the gel on the flat surface to be hardened and cooled (about 30 minutes).

6. When the gel is hardened, remove the combs and put it into electrophoresis with $1 x$ TBE buffer.

7. From $20 \mu \mathrm{l}$ of amplicon sample for electrophoresis is using $5 \mu \mathrm{l}$ premixed with colour. The resulting amplicons are colored that there could be monitoring their movement in the gel and to be heavier and thus sank to the bottom of the well.

Note: For colouring samples are used specially made or bought color Loading Day. Color is kept in the fridge, for longer periods kept in freez at $-20^{\circ} \mathrm{C}$.

8. Prepare samples for electrophoresis mixing with colour. On a piece of Parafilm make balls of approximately $1 \mu$ l loading color in the number of how many samples and one more for the marker. A marker is placed in an amount of $5 \mu \mathrm{l}$. Marker is kept in the freezer, and one that is used in the refrigerator.

9. Prepared samples are inflicting to wells required changing the extensions after each sample.

10. The electrophoresis is carried out under conditions of constant power of $100 \mathrm{~V} / 40 \mathrm{~mA}$ in a period of about $1 \mathrm{~h}$ or until the front of colour comes to about $1 \mathrm{~cm}$ before the bottom edge of the gel. Turn off the power source before releasing a gel from the device.

11. After completion of the electrophoresis gel to incubate for 15-30 minutes in a solution of Ethidium bromide (EtBr) in distilled water to a final concentration of $0.5 \mu \mathrm{g} / \mathrm{ml}$. EtBr is a powerful mutagen and require special precautions in their work. Gel put into solution with Ethidium bromide using a wide spatula, container must be close. Gel leave for 15 minutes in order to reach the visualization of PCR products. When working with EtBr use 2 pairs of gloves, while the other pair touches only what is in constant contact with EtBr.

Note: An alternative method of staining the gel with the method in which a $0.1 \%$ solution of EtBr added directly to the dissolved gel (before pouring into 
the mold) in an amount of $5 \mu \mathrm{l}$ to $100 \mathrm{ml}$ of the gel. In this way, samples are immediately color while flowing through the agarose gel.

12. Flushing gel (bleaching) is carried out by incubation in distilled water for 15-20 min.

13. Observing the gel is carried out with UV transilluminator. DNA fragments are visible as strips of orange color. Gel expose UV-light as short as possible due to the fact that UV light gradually destroying and damages the DNA. UV light is also dangerous for the observers so be sure to use protection during observation.

14. Check the results by comparing the strip markers and reactions both positive and negative controls.

15. Take an image with camera with a yellow filter.

16. The gel inserts in a plastic bag that sticks and then into a container for destruction EtBr or leave it under UV light or direct sunlight until dries.

\section{DNA cloning}

Cloning of the DNA or recombinant DNA technology is one of the methods of molecular biology, which enables obtaining of identical copies of a specific DNA fragment or the gene of interest. Cloning is accomplished by incorporating the desired gene fragment into genom of plasmid or virus (phage) of certain bacteria, so that the inserted DNA sequence multiplies along with its replication. The genome of a carrier in which is incorporated a desired DNA fragment is referred to as a vector. Bacteria Escherichia coli is the most commonly used host which enables amplification of the vectors, although the vectors are designed for other types of bacteria and some simple eukaryotic cells such as yeast (Lodish et al. 2000).

In general, the DNA fragment that we want to clone is obtained using polymerase chain reaction (PCR). Subsequently, these fragments are combined with vector DNA and then inserted into a host organism which easy-to-grow, such as E. coli bacteria. This will generate a population of organisms in which recombinant DNA molecules are replicated along with the host DNA.

Although a very large number of host organisms and molecular cloning vectors are in use, the great majority of molecular cloning experiments begin with a pGEM ${ }^{\circledR}$-T Easy plasmid vector and a laboratory strain DH5a of the bacterium $E$. coli. The pGEM $^{\circledR}-\mathrm{T}$ Easy vectors are linearized vectors with a single 3 -terminal thymidine at both ends which preventing recircularization of the vector and improve the efficiency of ligation of PCR product with adenine at both 3' ends generated by thermostable polymerase such as GoTaq, Taq and AmpliTaq as well as Tfl and Tth polymerase. In addition, the pGem-T easy vector containing the gene for bacterial resistance to ampicillin as well as the T7 and SP6 RNA polymerase promoter flanking a polylinker region (the multiple cloning region) within the lacZ gene coding region of the enzyme 
beta-galactosidase. Insertion of a DNA sequence into a plasmid leads to inactivation and unable to create a beta-galactosidase, and so that the colonies with a recombinant DNA molecule identified as white colonies on the medium containing lactose. The clones containing the plasmid with the PCR product produced white colonies, and plasmid clones with no PCR products give blue colonies on the medium with lactose because of the lacZ gene is functional and produces beta-galactosidase. Within polylinker region there are numerous restriction sites for different restriction enzymes (endonucleases) that allow the separation of the inserted DNA fragment from the plasmid (Lodish et al. 2000; Russell \& Sambrook 2001).

The cloning of any DNA fragment essentially involves several steps: (1) amplification of DNA fragment that we want to clone, (2) ligation of PCR product with vector DNA (creation of recombinant DNA), (3) insertation of recombinant DNA into bacteria cells, (4) the reproduction of bacteria together with the recombinant DNA, (5) screening clones with recombinant DNA, and (6) plasmid extraction and purification from the bacterial cells.

\subsection{Ligation of PCR product with vector}

The use of pGEM-T Easy Vector Systems Kit (Promega GmbH, Mannheim, Germany; https://promega.com) based on using pGEMT Vectora which was linearized, containing one nucleotide thymine at the $3^{\prime}$ end of both strands, has a gene responsible for resistance to amplicilin and a multiple cloning region that recognize a number of restriction enzymes. Ligation of the PCR product and the vector is simple and is based on the complementarity between adenine and thymine since most of the polymerase during synthesis of the fragment in a PCR reaction added one adenine nucleotide at the ends of DNA fragment.

\section{Kit Contents:}

1. pGEM $^{\circledR}-\mathrm{T}$ Vector $(50 \mathrm{ng} / \mu \mathrm{l})$

2. Control Insert DNA $(4 \mathrm{ng} / \mu \mathrm{l})$

3. T4 DNK Ligase

4. 2X Rapid Ligation Buffer, T4 DNK Ligase

5. JM109 Competent Cells, High Efficiency (optional, since there is posibility to purchase kit without the transformed cells)

\section{Protocol (Anonymous, 2015b):}

1. Thaw pGEM $^{\oplus}-\mathrm{T}$ vector, $2 \mathrm{X}$ Rapid Ligation buffer and control insert DNA, than vortex (it is especially important vortex the buffer vigorously because the salt in buffer can precipitated during store), spin down briefly and put on ice. Enzyme T4 DNA ligase is constantly kept on ice and no mix. 
2. Vortex PCR product, spin down and put on ice.

3. Prepare mix according table 5.

\begin{tabular}{|l|l|l|}
\hline \multicolumn{1}{|c|}{ Reaction component } & \multicolumn{1}{c|}{ Sample } & \multicolumn{1}{c|}{ Positive control } \\
\hline 2X Rapid Ligation Buffer & $5 \mu \mathrm{l}$ & $5 \mu \mathrm{l}$ \\
\hline $\begin{array}{l}\text { pGEM } \\
(50 \mathrm{ng})\end{array}$ & $1 \mu \mathrm{l}$ or pGEM ${ }^{\circledast}$-T Easy Vector & $1 \mu \mathrm{l}$ \\
\hline PCR product & $3 \mu \mathrm{l}^{\star}$ & - \\
\hline Control insert DNA & - & $2 \mu \mathrm{l}$ \\
\hline T4 DNA Ligase (3 Weiss units/ $\mu \mathrm{l})$ & $1 \mu \mathrm{l}$ & $1 \mu \mathrm{l}$ \\
\hline Nuclease free $\mathrm{H}_{2} \mathrm{O}$ & $\begin{array}{l}\text { up to a final } \\
\text { volume of } 10 \mu \mathrm{l}\end{array}$ & $\begin{array}{l}\text { up to a final volume of } \\
10 \mu \mathrm{l}\end{array}$ \\
\hline
\end{tabular}

Table 5: The amounts and components for the preparation of mix for application pGEM-T Easy Vector Systems kit.

* The amount of PCR product is determined depending on the concentration of the PCR product and the desired ratio of the vector and the PCR product. The ratio of the vector and the PCR product is from $8: 1$ to $1: 8$, but it is the best to use a ratio of from $3: 1$ to $1: 3$. The propriat amount of PCR product was calculated according to the following equation:

$\mathrm{ng}$ of vector $\times \mathrm{kb}$ size of insert $\mathrm{kb}$ size of vector

Example: If ratio of the PCR product and vector is 3:1 and size of PCR fragment $1000 \mathrm{bp}$, than you should add $50 \mathrm{ng}$ of the PCR product

$$
\text { because } \frac{50 \mathrm{ng} \times 1 \mathrm{~kb}}{3 \mathrm{~kb}} \times 3=50 \mathrm{ng}
$$

4. In most cases you can use $3 \mathrm{ml}$ of the PCR product. Make a mix containing all components except sample (PCR product), vortex and spin down briefly and then divide by $7 \mathrm{ml}$ in tubes of $1.5 \mathrm{ml}$. After that in the tubes added to $3 \mathrm{ml}$ of the PCR product, vortex, spin down and incubate overnight at $4^{\circ} \mathrm{C}$ (refrigerated).

\subsection{Transformation of cell of Escherichia coli strain DH5 $\alpha$}

Instead of transformed cells that are purchased in a kit, transformed cells of E. coli strain DH5a can be used. Transformation of E. coli cells includes opening of a pore in the cell wall of the bacteria and increase the number of receptor sites in order to put plasmid with the desired PCR product into bacterial cells. 
Protocol (Gallitelli et al., Dipartimento di Scienze del suolo, della pianta e degli alimenti, Università degli Studi di Bari Aldo Moro, Bari, Italy, personal communication):

1. Inoculate bacteria cells in $3 \mathrm{ml}$ of LB liquid media and incubate overnight at $37^{\circ} \mathrm{C}$ with constant stirring at $250 \mathrm{rpm}$ (to do this in the same day as ligation of the PCR product).

2. Transfer the $50 \mathrm{ml}$ suspension of bacteria in a new $10 \mathrm{ml}$ of LB liquid media and incubate for $3.5 \mathrm{~h}$ at $37^{\circ} \mathrm{C}$ with constant stirring at $250 \mathrm{rpm}$ (the bacteria suspension transfer in the new tube using large pipette or small pipette, but in this case, cut off the top of tips).

3. After incubation, centrifuge bacteria suspension at $4^{\circ} \mathrm{C}$ for $5 \mathrm{~min}$ at 6000 rpm.

4. Discard the supernatant and add $5 \mathrm{ml}$ of transformation buffer on the opposite side of the pellet. Gently resuspend pellet tapping of the tube with your finger, incubate on ice for $20 \mathrm{~min}$, and then centrifuge for 5 min at $6000 \mathrm{rpm}$ at $4^{\circ} \mathrm{C}$.

5. Discard the supernatant and add $600 \mu$ of transformation buffer on the opposite side of the pellet. Gently resuspend pellet tapping of the tube with your finger and incubate on ice for $2 \mathrm{~h}$.

6. After incubation, bacteria cells are transformed and prepared for cloning.

\section{Transformation buffer}

- $735 \mathrm{mg}$ of $\mathrm{CaCL}_{2} \mathrm{xH}_{2} 0$ (necessary to dilate the pores of the cell wall)

- $5 \mathrm{mg}$ of thymidine (active receptors of the bacterial cell)

- $1 \mathrm{ml}$ of $1 \mathrm{M}$ Tris-HCl pH 7.5 (buffer function)

Make up the volume to $100 \mathrm{ml}$ with sterile $\mathrm{H}_{2} \mathrm{O}$, and sterilize by bacteriological filter.

Instead of transformation buffer it can be used $100 \mathrm{mM} \mathrm{CaCl}_{2}$ sterilized in the autoclave for 20 minutes.

\subsection{Insertation of plasmid into transformed bacteria cells}

(Anonymous, 2015b)

1. Add $100 \mu \mathrm{l}$ of transformed cells in $10 \mu \mathrm{l}$ of ligation product and gently mix by tapping of the tube with your finger, and than incubate on ice for 30 min. Make sure you work on ice and the bacteria cell add using large pipette or small pipette, but in this case, cut off the top of tips. Before each addition of the bacteria cell, you must mix gently suspension of bacterial cells by tapping with your finger.

2. After that, incubate tube in water bath at $42^{\circ} \mathrm{C}$ for $3 \mathrm{~min}$. 
3. After this incubation, the tubes put on ice for $2 \mathrm{~min}$, and than incubate at room temperature for additional $2 \mathrm{~min}$.

4. After this incubation, in each tube add $300 \mu \mathrm{l}$ of LB liquid media and incubate for $1 \mathrm{~h}$ at $37^{\circ} \mathrm{C}$ with constant stirring at $150 \mathrm{rpm}$.

\subsection{Plating of bacteria cells (Anonymous, 2015b)}

1. Thaw LB media with agar and cool down at $50^{\circ} \mathrm{C}$, and then add $1 \mathrm{ml}$ of ampicillin concentration of $100 \mathrm{mg} / \mathrm{ml}$ per $1 \mathrm{ml}$ of the media.

2. Spilled the media in Petri dishes and allow tightening (for each sample prepared by 2 Petri dishes).

3. Distribute carefully $40 \mu \mathrm{l}$ of $\mathrm{X}-\mathrm{Gal}$ onto Petri dishes $15 \mathrm{~min}$ before planting of bacteria cell and leave Petri dishes to absorb X-Gal (X-Gal applied by pipette as drops and then evenly distributed on the media).

4. Aftre that, add $100 \mu \mathrm{l}$ of transformed bacteria cells by pipette as drops and distribute well onto the media (be sure to use a smaller pipette but cut off the top of tips).

5. Spin-down the remaining of the bacteria suspension, discard $100 \mu \mathrm{l}$ of the supernatant and gently resuspend pellet in the remaining volume by tapping with your finger.

6. Add $100 \mu \mathrm{l}$ of bacteria suspension onto second Petri dishes and distribute well onto the media.

7. Incubate Petri dishes over night at $37^{\circ} \mathrm{C}$, so the lid downwards.

8. After incubation, appears white (which contain plasmid) and blue colonies (which do not contain plasmid).

9. Petri dishes kept in the refrigerator until the moment of purification of plasmid.

\section{$\underline{\mathrm{X}-\mathrm{Gal}}$}

Dissolve $100 \mathrm{mg}$ of 5 -bromo-4-chloro-3-indolyl- $\beta$-D-galactopyranoside in $2 \mathrm{ml}$ of $2 \mathrm{NN}$ dimethyformamide and store at $-20^{\circ} \mathrm{C}$.

\subsection{Plasmid DNA extraction from Escherichia coli (Gallitelli} et al., Dipartimento di Scienze del suolo, della pianta e degli alimenti,

Università degli Studi di Bari Aldo Moro, Bari, Italy, personal communication)

1. Inoculate $3 \mathrm{ml} \mathrm{LB}$ media containing $100 \mu \mathrm{g} / \mathrm{ml}$ ampicilin with one white colony picked up from Petri dishes and incubate at $37^{\circ} \mathrm{C}$ with constant stirring at $250 \mathrm{rpm}$.

2. After incubation, transfer part of suspension in a $1.5 \mathrm{ml}$ tube and centrifuge for $30 \mathrm{~s}$ at $14000 \mathrm{rpm}$. Discard the supernatant and dry tube on the filter paper. Repeated this step with the rest of suspension. 
3. Add $350 \mu \mathrm{l}$ of STET solution in each tube ( $8 \%$ sucrose, $20 \mathrm{mM}$ Tris- $\mathrm{HCl}$ $\mathrm{pH} 8,50 \mathrm{mM}$ EDTA, $0.5 \%$ Triton) and $15 \mu \mathrm{l}$ of $20 \mu \mathrm{m} / \mu \mathrm{l}$ lysozyme and dissolve pellet on vortex.

4. Incubate tubes on boiling water for $40 \mathrm{~s}$ and immediately put on ice and incubate for $5 \mathrm{~min}$.

5. After incubation, samples centrifuge for $20 \mathrm{~min}$ at $14000 \mathrm{rpm}$.

6. After centrifugation, remove the bacterial chromosome DNA with a sterile toohtpick.

7. Add $175 \mu \mathrm{l}$ of phenol and $175 \mu \mathrm{l}$ of chloroform: isoamyl alcohol mixture in 24:1 proportion, vortex for $40 \mathrm{~s}$ and centrifuge for $10 \mathrm{~min}$ at 14000 rpm.

8. Recover the aqueous phase in new $1.5 \mathrm{ml}$ tube and add $200 \mu \mathrm{l}$ of $5 \mathrm{M}$ ammonium acetate $\mathrm{pH} 5.5$ and $1 \mathrm{ml}$ of cold absolte ethyl alcohol, and vortex.

9. Centrifuge tubes at $14000 \mathrm{rpm}$ for $10 \mathrm{~min}$, and than discard the supernatant and dry well tube on the filter paper.

10. Wash the pellet with $500 \mu \mathrm{l}$ of cold $70 \%$ ethyl alcohol, and than centrifuge for $3 \mathrm{~min}$ at $14000 \mathrm{rpm}$. Discard supernatant by pipette and dry pellet at $65^{\circ} \mathrm{C}$ for $5 \mathrm{~min}$.

11. Resuspend pellet in $50 \mu \mathrm{l}$ of TE buffer $(10 \mathrm{mM}$ Tris- $\mathrm{HCl} \mathrm{pH} 8,1 \mathrm{mM}$ EDTA) and digest RNA with $1 \mu \mathrm{l}$ of RNaseA (concentration $10 \mathrm{mg} / \mathrm{ml}$ ) at $37^{\circ} \mathrm{C}$ for $30 \mathrm{~min}$.

12. Add $30 \mu \mathrm{l}$ of PEG-NaCl (20\% Polyetilen glikol 6000 and $2.5 \mathrm{M} \mathrm{NaCl})$ in each tube and mix carefully on vortex. Incubate samples on ice for $1 \mathrm{~h}$.

13. After incubation, centrifuge tubes for $10 \mathrm{~min}$ at $14000 \mathrm{rpm}$.

14. Discard supernatant and wash pellet with $300 \mu \mathrm{l}$ of cold $70 \%$ ethyl alcohol.

15. Centrifuge tubes for $2 \mathrm{~min}$ at $14000 \mathrm{rpm}$, discard supernatant and dry pellet at $65^{\circ} \mathrm{C}$ for $5 \mathrm{~min}$.

16. After that, dissolve pellet in $30 \mu \mathrm{l}$ of RNase free water.

The pellet represents the cloned target DNA fragment wich was obtained in a large amount and can be used for further analizis using other methods, such as, for example, sequencing to verify the identity or other molecular methods for identification of phytopathogenic viruses, fungi and fungus-like organisms.

\section{References}

Anderson, P. K., Cunningham, A. A., Patel, N. G., Morales, F. J., Epstein, P. R. \& Daszak, P. (2004). Emerging infectious diseases of plants: pathogen pollution, climate change and agrotechnology drivers. Trends in Ecology \& Evolution 19, 535-544. DOI: https://doi.org/10.1016/j.tree.2004.07.021 
Anonymous (2008). RNAqueous ${ }^{\circledR}$ Kit (Part Number AM1912), Protocol. https://tools.thermofisher.com/content/sfs/manuals/cms_055306.pdf

Anonymous (2012a). Qiagen ${ }^{\circledast}$ OneStep RT-PCR Handbook. https://www. qiagen.com/us/resources/download.aspx?id=57743726-84e1-423a-9d8fa3fa89bbe7eb\&lang=en

Anonymous (2012b). RNeasy ${ }^{\oplus}$ Mini Handbook, Fourth Edition. http://www. bea.ki.se/documents/EN-RNeasy\%20handbook.pdf

Anonymous (2015a). DNeasy ${ }^{\circledast}$ Plant Handbook. https://www.researchgate. net/file.PostFileLoader.html?id=56ff54f2eeae39355963f1b1\&assetKey=AS \%3A346292619366400\%401459574002159

Anonymous (2015b). pGEM ${ }^{\ominus}-\mathrm{T}$ and pGEM $^{\ominus}-\mathrm{T}$ Easy Vector Systems, Technical Manual. https://www.promega.com/-/media/files/resources/protocols/ technical-manuals/0/pgem-t-and-pgem-t-easy-vector-systems-protocol. pdf.

Bekesiova, I., Nap, J. P. \& Mlynarova, L. (1999). Isolation of high quality DNA and RNA from leaves of the carnivorous plant Drosera rotundifolia. Plant Molecular Biology Reporter 17, 269-27. DOI: https://doi.org/ 10.1023/A:1007627509824.

Day, J. P. \& Shattock, R. C. (1997). Aggressiveness and other factors relating to displacement of population of Phytophthora infestans in England and Wales. European Journal of Plant Patholoogy 103, 379-391. DOI: https:// doi.org/ 10.1023/A:1008630522139.

Iandolino, A. B., Goesda Silva, F., Lim, H., Choi, H., Williams, L. E. \& Cook, D. R. (2004). High-quality RNA, cDNA, and derived EST libraries from grapevine (Vitis vinifera L.). Plant Molecular Biology Reporter 22, 269-278. DOI: https://doi.org/10.1007/BF02773137

Konstantinova, P., Bonants, P. J. M., van Gent-Pelzer, M. P. E., van der Zouwen, P. \& van den Bulk, R. (2002). Development of specific primers for detection and identification of Alternaria spp. in carrot material by PCR and comparation with blotter and plating assays. Mycological Research 106, 23-33. DOI: https://doi.org/10.1017/S0953756201005160.

Kroon, L. P. N. M., Verstappen, E. C. P., Kox, L. F. F., Flier, W. G. \& Bonants, P. J. M. (2004). A Rapid Diagnostic Test to Distinguish Between American and European Populations of Phytophthora ramorum. Phytopathology 94, 613-620. DOI: https://doi.org/10.1094/PHYTO.2004.94.6.613.

Krstić, B., Bulajić, A. \& Đekić, I. (2008). Tomato spotted wiltvirus, TSWVStandardna operativna procedura za fitopatološke dijagnostičke laboratorije. Univerzitet u Beogradu-Poljoprivredni fakultet i Ministarstvo poljoprivrede, vodoprivrede i šumarstva, Beograd.

Krstić, B., Bulajić, A., Ivanović, M., Stanković, I. \& Vučurović, A. (2010). Alfalfa mosaicvirus, AMV-Standardna operativna procedura za fitopatološke dijagnostičke laboratorije. Univerzitet u Beogradu-Poljoprivredni fakultet i Ministarstvo poljoprivrede, vodoprivrede i šumarstva, Beograd. 
Lee, P. Y., Costumbrado, J., Hsu, C. Y. \& Kim, Y. H. (2012). Agarose Gel Electrophoresis for the Separation of DNA Fragments. Journal of Visualized Experiments 62, e3923. DOI: https://doi.org/10.3791/3923

Lodish, H., Berk, A., Zipursky, S. L., Matsudaira, P., Baltimore, D. \& Darnell, J. (2000). Molecular cell biology, $4^{\text {th }}$ edition. New York: W. H. Freeman, DOI: https://doi.org/10.1016/S1470-8175(01)00023-6

McKirdy, S. J., Washer, S., Berryman, D., Sargent, K., Selladurai, S., Jones, R. A. C. \& Coutts, B. (1998). Virus testing in chickpea and lentil seed. Pea seedborne mosaic and other viruses. Pulse Research and Industry Development in Western Australia, 1998. Updates, Observation City, pp. 94-95. https:// doi.org/10.1094/PDIS-11-15-1249-RE

McPherson, M. J. \& Møller, S. G. (2000). PCR. BIOS Scientific Publishers Ltd.

Miller, S. A., Beed, F. D. \& Harmon, C. L. (2009). Plant disease diagnostic capabilities and networks. Annual Review of Phytopathology 47, 15-38. DOI: https://doi.org/10.1146/annurev-phyto-080508-081743

Reece, R. J. (2004): Analysis of genes and genomes. John Wiley \& Sons, ISBN-10: 1449635962

Russell, D. W. \& Sambrook, J. (2001). Molecular cloning: a laboratory manual. Cold Spring Harbor, N.Y: Cold Spring Harbor Laboratory, https://doi. org/10.1086/394015

Sellner, L. N. \& Turbett, G. R. (1998). Comparison of three RT-PCR methods. Biotechniques 25, 230-234.

Strange, R. N. \& Scott, P. R. (2005). Plant disease: a threat to global food security. Annual Review of Phytopathology 43, 83-116. DOI: https://doi.org/10.1146/ annurev.phyto.43.113004.133839

White, T. J., Bruns, T., Lee, S. \& Taylor, J. (1990). Amplification and direct sequencing of fungal ribosomal RNA genes for phylogenetics. In: M. Innis, D. Gelfand, J. Sninsky, T. White (eds.), San Diego Academic Press, Inc., PCR protocols: A guide to methods and applications, pp. 315-322. DOI: https:// doi.org/10.1016/B978-0-12-372180-8.50042-1.

Zeng, Y. \& Yang, T. (2002). RNA Isolation From Highly Viscous Samples Rich in Polyphenols and Polysaccharides. Plant Molecular Biology Reporter 20, 417a-417e. DOI: https://doi.org/10.1007/BF02772130 